\title{
The British Polar Year Expedition to Fort Rae, North-West Canada, I932-33
}

\author{
By J. M. StAGG
}

$\mathrm{T}$ HOUGH the special and continuous needs of meteorology, terrestrial magnetism and allied sciences for systematic observations over wide areas and in high latitudes had been felt long before 1882-83, it was not until then that a largescale effort was made by twelve countries to study events in those subjects through a full year according to an agreed plan. In collaboration with Canada, Britain's share in that First International Polar Year, as the twelve months ending August 1883 has come to be called, was to equip a party under Capt. Dawson, R.E., for continuous observa. tions in meteorology, terrestrial magnetism and aurora to be carried out at Fort Rae, a trading outpost of the Hudson's Bay Company on the Great Slave Lake, North-West Canada. Practically and scientifically, from the point of view of international collaboration as wêll as that of Britain's own participation in it, the year's activities were completely successful.

As the jubilee of that First Polar Year approached, it was felt in many quarters that no time could be more appropriate for a repetition on a much more extensive and intensive basis. In the three primary subjects then investigated, advances in recent years have been large, and mainly all in the direction of indicating that further progress depended on the gathering of more precise observational material from a still wider field and to the limits of the atmosphere. The sequences of weather changes over limited regions like Britain in moderate latitudes might well be determined by conditions in the stratosphere far to the north or south, days or weeks ahead: the short-period irregular changes in the earth's mag. netic field, known to be intimately associated with the state of ionisation in the conducting layers of the high atmosphere, seemed to be bound up with auroral activity on one hand and the interruption of long-distance wireless communication on the other. To a few even it has seemed not improbable that these two domains, the apparently locally determined meteorology and the more cosmically produced aurora and its effect on the earth's magnetic field through the intermediary of the ionosphere, might be interconnected. Such were the questions: in many cases speculation and theory had outstripped fact.

So in 1929 the time was ripe for the proposal of a Second Polar Year for 1932-33. An International Polar Year Commission was set up with the directors of the meteorological services of many countries as members and Dr. la Cour of Copenhagen as its president. National committees were constituted to carry out the general recommendations in each country. In Britain, with Sir Henry Lyons as its chairman, and Dr. G. C. Simpson as secretary, the National Polar Year Committee has had representatives from the Royal
Societies of London and Edinburgh and from six other interested institutions, A grant-in-aid of $£ 10,000$ by the Government through the Air Ministry has been the primary source of supply for the Committee's activities, though many manufacturing and wholesale firms have contributed to the fund by generous gifts of food and instrumental equipment and even of money.

Britain's share in the international programme has been fourfold :

(1) The provision of new instruments and facilities for conforming to the general plan of observations at some permanent meteorological stations and observatories in the country as well as on ships at sea.

(2) An intensified programme of auroral observations and photography in Scotland and in the Orkney and Shetland Islands.

(3) An extensive and novel series of observations on the variation in height and intensity of ionisation of the conducting layers in the high atmosphere, by Prof. E. V. Appleton and his party at Troms $\varnothing$.

(4) The equipment and manning of a station at Fort Rae, Canada, for complete and continuous observations in meteorology, terrestrial magnetism, aurora and atmospheric electricity.

The Fort Rae party under J. M. Stagg comprised Messrs. W. R. Morgans, P. A. Sheppard, and W. A. Grinsted (Meteorological Office) with Mr. A. Stephenson (Cambridge) as observers, and Mr. J. L. Kennedy as mechanic and steward. With sixteen tons of instrumental and foodstuff equipment, the party left England in May 1932 and journeyed by the usual route to Edmonton, Alberta, thence northerly for about a thousand miles, using the Hudson's Bay Company's river transport for the trip down the Athabasca and Slave Rivers, and so across the Great Slave Lake to its northern extremity. The site of the station was reached by the middle of June.

To ensure that all the instrumental equipment would be in full running order and the routine of observation thoroughly established by August 1, the starting date for the overlapping 'year' of thirteen months, every minute before then was required for erecting special huts and getting the autographic recording instruments in action. These covered every one of the main aspects of meteorology and terrestrial magnetism, and included a new type of magnetograph designed at Copenhagen, in which the variometers for the force components were optically compensated for temperature changes, and with a recorder arranged so that the time of incidence of sudden changes in the magnetic field could be read with an accuracy of two seconds. It is of interest to note that, using this magnetograph, a 'sudden commence- 
ment' of a magnetic disturbance on April 30, 1933, was judged to appear practically simultaneously at places so far apart as Copenhagen, Thule (in north-west Greenland) and Fort Rae.

Nearly all recording instruments were run in duplicate to make sure that the records would be as complete as possible, the secondary records in most cases providing the additional safeguards of furnishing data with other characteristics, as, for example, a more open time-scale or lower sensitivity.

As part of the programme of meteorological work, more than four hundred pilot balloon ascents were made during the term of occupation of the station and twenty-eight ballons sondes were sent up. The hydrogen for this work was manufactured on the spot in a new apparatus designed at the Airship Works, Cardington, and was produced by the interaction of granulated silicon with heated caustic soda. Two of the instruments from ballons sondes released in winter with surface temperatures about $-30^{\circ} \mathrm{C}$. attained heights of $16 \mathrm{~km}$. In both cases, the base of the stratosphere was very well marked at $8.5 \mathrm{~km}$. and with temperatures about $-60^{\circ} \mathrm{C}$.

With Fort Rae in an exceptionally good position relative to the zone of maxim 'im auroral frequency, much importance was attached to the observations and photography of aurora for precise determinations of its height and orientation. To a substation (which was actually the site of the station in the First Polar Year fifty years ago) some $25 \mathrm{~km}$. to the south-east, a telephone line was erected allowing photographs of the aurora to be taken simultaneously by cameras specially designed for auroral work in Norway. From these pairs of photographs, some 4,700 of which were taken by the party during the stay at Rae, it is hoped to obtain much definite information about aurora in that part of Canada. Although the period was so near the minimum of the present cycle of solar activity, aurora was observed at some time on every night when conditions were practicable. It was not infrequent during the winter months for aurora to continue almost uninterruptedly for fifteen hours.
In addition to the activities in these, the main lines of investigation, observations in atmospheric electricity claimed much attention. Continuous records of the potential gradient of the earth's electric field near the surface were maintained autographically, and frequent measurements of air-earth current and small ion content of the air were made. Experiments were also carried out to determine the nature of the diurnal variation of these quantities and also of the rate of production of ions near the ground.

The winter conditions at Rae during 1932-33 were characterised more by the steadiness of the cold than by extremes of temperature reached. Over the seven months ending April 30, 1933, the average temperature was $-20^{\circ} \mathrm{C}$, , but the lowest average for any single month was only $-31^{\circ} \mathrm{C}$.January and February were almost the same in this-and the lowest daily mean was only $-40^{\circ} \mathrm{C}$. During the short warm summer, daily temperatures frequently exceeded $20^{\circ} \mathrm{C}$.

The party returned from Rae in September and early October 1933 with a very large amount of observational matter for further study. It is now the intention that each country participating in the international programme should make all its data available by reduction and publication as early as possible, so that the larger and more important task of co-ordination of the results from all the stations may not be delayed. In many ways it was unfortunate that the Second Polar Year should have coincided with times of such grave financial stringencies in so many countries. But the difficulties encountered in the preparations both by the International Commission responsible for the general organisation of the Polar Year activities and by the individual national committees in each country served to emphasise the value of the work. It is certainly illuminating that forty-six different countries have taken part in the programme in one way or another, and of these, twenty-three have set up extra stationsin many cases more than one-either within their own territory to extend the number of their regular observatories, or outside their own lands as temporary observation posts.

\section{Progress of Industrial Research}

$I^{\mathrm{N}}$ N a recent address Dr. F. A. Freeth made an eloquent protest against the habit in Great Britain of always classifying science as something apart from ordinary life. It would be difficult to imagine a document better fitted to demonstrate the essential place of science in our ordinary everyday life, or to inspire a general confidence in scientific workers and science by the public, than the eighteenth annual report of the Department of Scientific and Industrial Research.* Published within a couple of days of Dr. Freeth's address,

* Department of Scientific and Industrial Research. Report for the Year 1932-33. (Cmd. 4483.) Pp. iv +189. (London: H.M. Stationery Office, 1934.) $3 s$. net. the report describes contributions made by the work of the Department to every major need of our social and industrial life. The comparatively

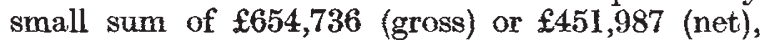
which represents the expenditure of this Department for the year ending March 31, 1933, represents also a contribution to the efficiency of every department of State and to the recovery or the prosperity of many industries, the true value of which it is impossible to assess in cash, but which repeatedly has earned dividends many hundred. fold on the expenditure involved.

Even this expenditure, however, represents a further decrease on that recorded in the previous 